\author{
Stupnytska T. \\ Ph.D., Associate Professor \\ E-mail: t.stupnitska@gmail.com \\ Gulavska K.I. \\ Undergraduate \\ Department of Accounting and Auditing \\ Odessa National Academy of Food Technologies \\ Kanatna str., 112, Odessa, Ukraine, 65039 \\ E-mail: katyagulavska@gmail.com
}

\title{
FIXED ASSETS OF THE ENTERPRISE: ASPECTS OF THEORETICAL APPROACHES TO DETERMINATION OF CONCEPT AND EFFICIENCY OF THEIR USE
}

In the article economic publications on the issues of a concept, classification and efficiency of use of the fixed assets of the enterprise have been considered. The essence of the category "fixed assets" and their classification in the economic literature and by normative sources have been determined. The directions of realization of the fixed assets analysis have been distinguished and indices for realization of the analysis have been systematized.

Keywords: fixed assets, classification of the fixed assets, analysis of the fixed assets of the enterprise, indices of motion of the fixed assets; indices of technical state of the fixed assets; indices of efficiency of the fixed assets.

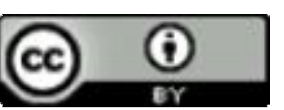

This work is licensed under a Creative Commons Attribution 4.0 International License http://creativecommons.org/licenses/by/4.0/
Statement of the problem and its connection with important scientific and practical tasks. One of the major factors of increase of efficiency of production is material provision it with the fixed assets. An enterprise retains them with the aim of use in the process of production, renting to other entities or for implementation of administrative and sociocultural functions and so on.

Activity of all enterprises begins with forming of the fixed assets that are the material and technical base of any enterprise, it is impossible to conduct economic activity at an enterprise without them. Composition and structure of the fixed assets determine the type of activity and production capacity of an enterprise, and the state and effective use in direct ratio influence the outcomes of its economic activity, and their effective use gives the new opportunities for expansion of an enterprise potential. For obtaining the income, that is basic for the enterprise, it is necessary to reach many aims among which are modernisation of operating and introduction to exploitation the new fixed assets and their effective use. It is especially relevant for industrial, agricultural enterprises, exactly for them the lion's share of property is occupied by the fixed assets.

The analysis of the latest publications on the problem. The issue of the concept, classification and efficiency of the use of the fixed assets was studied in the scientific works, related to the economic analysis, management of the industrial enterprise, financial accounting, administrative accounting, financial management, theory and practice of investing in securities by such authors as: Andriichuk V., Butynets F., Boiko V., Biluha M., Vashkiv P., Vozniuk A., Kuznetsov V., Lemishivskyi V., Ogiichuk M., Poddierohina A., Sopko V., Suharskyi V., Serdiuk V., Suk L., Tereshchenko V., Fedorets M., Khomiak R. and others. Also the issues of the concept and classification of the fixed assets are regulated by such normative sources as Regulations (standard) of accounting 7 "Fixed assets" and by Tax code of Ukraine. However frequent changes in the current legislation cause clarification of determination of this category and search of indices that represent the real efficiency of its use.

Forming of the aims of the research.The aim of the article is investigation of determination of category the "fixed assets", their classification and also indices of the efficiency of fixed assets use for organization of their accounting and effective management.

Giving an account of the main results and their substantiation. The fixed assets are the key element that provides effective activity of any enterprise. They are the basic constituent of the assets of an enterprise and make considerable influence on the financial result of its activity. Management of the fixed assets and their accounting are based on determination and economic classification of the fixed assets. Determination of the fixed assets is based on the fact that they are part of the assets, such as resources, controlled by an enterprise as a result of past events, use of which, as expected, will re- 
sult in appearance of the economic values in the future.

Determination of the category "fixed assets" by normative and economic sources is shown in table1.

Table 1

Determination of category "fixed assets" ' by normative and economic sources *

\begin{tabular}{|c|c|}
\hline Author & Definition \\
\hline $\begin{array}{l}\text { Tax code } \\
\text { of Ukraine [1] }\end{array}$ & $\begin{array}{l}\text { The fixed assets are material assets, including supplies of minerals of the areas of bowels (ex- } \\
\text { cept the cost of land, uncompleted capital investments, highways of general use, library and } \\
\text { archived funds, material assets cost of which exceeds } 6000 \mathrm{UAH} \text {, unproductive fixed assets } \\
\text { and non-material assets) that are appointed by the payer of tax for the use in economic activity } \\
\text { of payer of tax the cost of that exceeds } 6000 \mathrm{UAH} \text { and gradually diminishes in connection } \\
\text { with a physical or moral wear out and the expected term of the useful use (exploitations) of } \\
\text { that from the date of introduction to exploitation makes over one year (or operating cycle, if it } \\
\text { is longer than a year) }\end{array}$ \\
\hline $\begin{array}{l}\text { Regulations (standard) } \\
\text { of accounting } 7 \\
\text { "Fixed assets" } \\
(\mathrm{R}(\mathrm{S}) \mathrm{A})[2]\end{array}$ & $\begin{array}{l}\text { material assets, that an enterprise/establishment retains with the aim of the use of them in the } \\
\text { process of production/activity or supplying commodities, provision of services, leasing to oth- } \\
\text { er entity or for realization of administrative and sociocultural functions, expected term of the } \\
\text { useful use (exploitations) of that is more than one year (or operating cycle, if it is longer than } \\
\text { year). }\end{array}$ \\
\hline $\begin{array}{l}\text { International standard } \\
\text { of accounting } 16 \\
\text { "Fixed assets " } \\
(\mathrm{I}(\mathrm{S}) \mathrm{A})[3]\end{array}$ & $\begin{array}{l}\text { the fixed assets are material objects which: } \\
\text { a) are retained for use in production or supplying commodities or provision of services for } \\
\text { leasing or for administrative purposes; } \\
\text { b) will be used as expectation during more than one period. }\end{array}$ \\
\hline F. Butynets [4] & $\begin{array}{l}\text { Fixed assets are material assets that are retained with the aim of the use of production or sup- } \\
\text { plying commodities, provision of services, leasing to other entities or for realization of admin- } \\
\text { istrative and sociocultural functions, expected term of useful use is more than one year. }\end{array}$ \\
\hline $\begin{array}{l}\text { V. Boiko, } \\
\text { P. Vashkiv [9] }\end{array}$ & $\begin{array}{l}\text { Fixed assets are totality of facilities of labour which function in the field of material produc- } \\
\text { tion in unchangeable natural form for a long time and transfer their cost on the new created } \\
\text { product in parts to the extent of their wear out. }\end{array}$ \\
\hline M. Ogiichuk [5] & $\begin{array}{l}\text { Fixed assets are part of assets, such as resources, controlled by an enterprise as a result of past } \\
\text { events the use of that, as expected, will result in appearance of economic values in the future. }\end{array}$ \\
\hline $\begin{array}{l}\text { M.Fedorets, } \\
\text { V.Tereshchenko [6] }\end{array}$ & $\begin{array}{l}\text { The fixed assets are material assets that function in unchangeable naturally-material form dur- } \\
\text { ing a long period of time ( more than one year or more than one operating cycle, if it is more } \\
\text { than one year). To basic money belong: structures, buildings, land, transport vehicles, ma- } \\
\text { chines of equipment and others. }\end{array}$ \\
\hline $\begin{array}{l}\text { R.. Khomiak, } \\
\text { V. Lemishivskyi [10] }\end{array}$ & $\begin{array}{l}\text { Fixed assets are material values which are used during a period that exceeds one year, and the } \\
\text { cost of which gradually diminishes in connection with a physical and moral wear out. }\end{array}$ \\
\hline
\end{tabular}

One of the important issues of rational management of the fixed assets is its correct classification that requires permanent clarification. The most widespread in economic literature is the classification of the fixed assets by few basic features (table 2 ).

Classification of the fixed assets in the economic literature by few basic features*

\begin{tabular}{|c|l|l|}
\hline Classification feature & Classification group & \multicolumn{1}{c|}{ Definition } \\
\hline \multirow{3}{*}{ By functionality } & $\begin{array}{l}\text { productive } \\
\text { the fixed assets which directly participate in a productive } \\
\text { process or assist its realization (structures, buildings, power } \\
\text { machines and equipment, working machines and equipment } \\
\text { and others like that) that operate in the field of material } \\
\text { production; }\end{array}$ \\
\cline { 2 - 4 } & $\begin{array}{l}\text { the fixed assets which do not take direct or side participation } \\
\text { in the process of production and are intended mainly for } \\
\text { maintenance of communal and cultural and welfare necessi- } \\
\text { ties of workers (structures, building, equipment, machines, } \\
\text { vehicles and others like that) that are used in unproductive } \\
\text { field; }\end{array}$ \\
\hline
\end{tabular}


Continue of table 2

\begin{tabular}{|c|c|c|}
\hline Classification feature & Classification group & Definition \\
\hline \multirow{3}{*}{ By using } & active & all fixed assets that are used in economy \\
\hline & inactive & $\begin{array}{l}\text { the fixed assets that are not used in this period of time in } \\
\text { connection with the temporal reserving of enterprises or } \\
\text { separate workshops }\end{array}$ \\
\hline & reserved & $\begin{array}{l}\text { different equipment that is in reserve and is intended for the } \\
\text { change of objects of the fixed assets that left or are repaired; }\end{array}$ \\
\hline \multirow[t]{2}{*}{ By feature of belonging } & own & $\begin{array}{l}\text { own fixed assets are directly property of an enterprise and } \\
\text { have a source of their formation - payment to the registered } \\
\text { (ration) capital, additional capital from corresponding } \\
\text { sources on expansion of enterprise work, own incomes, pur- } \\
\text { poseful financing and purposeful entries; }\end{array}$ \\
\hline & leased & $\begin{array}{l}\text { leased fixed assets are those that are used on an enterprise but are } \\
\text { not its property, they are shown in the balance of lessor, possibility } \\
\text { of double account of the same facilities is excluded; }\end{array}$ \\
\hline \multirow{5}{*}{ By branch feature } & industrial & the fixed assets related to industry; \\
\hline & building & the fixed assets that relate to building; \\
\hline & agricultural & the fixed assets related to agriculture; \\
\hline & transport & the fixed assets related to transport; \\
\hline & connection & the fixed assets related to connection; \\
\hline
\end{tabular}

* It is made by authors with the use of sources $[7,8,11]$

By normative sources the classification of the fixed assets for the aims of accounting on the require- ments of R(S)A7 "Fixed assets" on groups and I(S)A 16 "Fixed assets" is divided into classes (pic. 1).
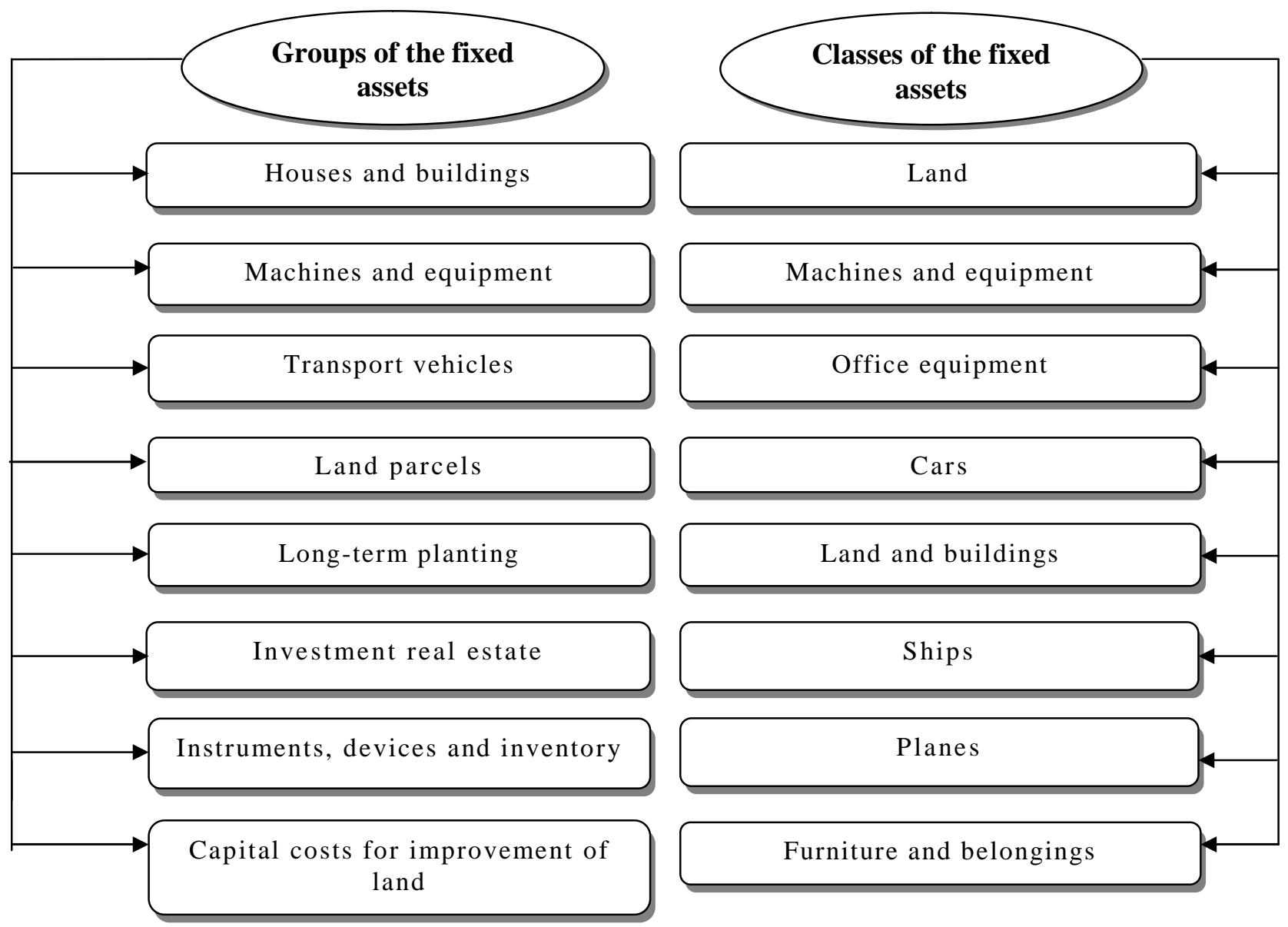

Pic. 1 - Distribution of the fixed assets according to the requirements of R(S)A7 "Fixed assets" and I(S)A 16 "Fixed assets" *

* it is made by authors with the use of sources [2,3] 
From pic. 1 we see, that in I(S)A 16, other inconvertible material assets, long-term planting, capital charges on improvements of land are not distinguished, but they are distinguished in separate groups in $\mathrm{R}(\mathrm{S}) \mathrm{A} 7$. Also in $\mathrm{I}(\mathrm{S}) \mathrm{A} 16$ there is envisaged possibility of association of separate insignificant assets (for example, tem- plates, instruments and stamps and others) in one object of the fixed assets, national standards eliminate such possibility.

Classification of the fixed assets by Tax code of Ukraine is shown in table 3 .

Table 3

Classification of the fixed assets on the Tax code of Ukraine [1]

\begin{tabular}{|c|l|}
\hline Group & \\
\hline Group 1 & Plots of land \\
\hline Group 2 & Capital costs for improvement of land unconnected with building \\
\hline \multirow{2}{*}{ Group 3 } & Houses, \\
\cline { 2 - 2 } & buildings, \\
\cline { 2 - 2 } & transmission devices \\
\hline \multirow{5}{*}{ Group 4 } & Machines and equipment \\
\cline { 2 - 2 } & $\begin{array}{l}\text { electronic calculating machines, other machines for automatic processing information, related } \\
\text { to them facilities of read-out or printing information, computer programs (except programs, } \\
\text { charges on acquisition which are considered to royalty, and/or programs which are considered } \\
\text { as intangible assets), other informative systems, switchboards, routers, modules, modems, } \\
\text { sources of trouble-free feed and facilities of their connecting to TCNS, telephones (including } \\
\text { cellular), microphones and portable radio transmitters the cost of which exceeds 2500 UAH }\end{array}$ \\
\hline Group 5 & Transport vehicles \\
\hline Group 6 & Instruments, devices, inventory (furniture) \\
\hline Group 7 & Animals \\
\hline Group 8 & Long-term planting \\
\hline Group 9 & Other fixed assets \\
\hline Group 10 & Library funds \\
\hline Group 11 & Less valuable inconvertible material assets \\
\hline Group 12 & Temporal (untitle) buildings \\
\hline Group 13 & Natural resources \\
\hline Group 14 & Inventory container \\
\hline Group 15 & Items of rent \\
\hline Group 16 & Long-term biological assets \\
\hline
\end{tabular}

Although there is a wide choice of classification of the fixed assets, offered in the economic literature and in normative sources we consider that for the aims of accounting it is necessary to use classification by $\mathrm{R}(\mathrm{S}) \mathrm{A} 7$, and for the aims of the fiscal accounting - by Tax code of Ukraine.

The fixed assets that are used by an enterprise during the conduct of economic activity need permanent control. An important issue in the process of management, accounting and control of the fixed assets of an enterprise is realization of their analysis. The analysis must be directed to determination of expediency and efficiency of the use of the fixed assets by comparison of costs on their acquisition and exploitation with profits from their use.

The global analysis of the fixed assets is conducted by such directions with the use of corresponding indices (table.4):

- analysis of the fixed assets motion;

- analysis of technical state of the fixed assets;

- analysis of efficiency of the use of the fixed assets application.

List and description of indices that are used for the analysis of the fixed assets*

\begin{tabular}{|c|c|c|}
\hline Indices & Methodology of calculation & Determination \\
\hline \multicolumn{3}{|c|}{ indices of motion of the fixed assets } \\
\hline Coefficient of receipt & $\begin{array}{l}\qquad \mathrm{C}_{\mathrm{r}}=\frac{\mathrm{FA}_{\mathrm{c}}}{\mathrm{FA}_{\mathrm{e}}} \text {, } \\
\text { where } \mathrm{C}_{\mathrm{r}}-\text { coefficient of receipt of the fixed } \\
\text { assets; } \\
\mathrm{FA}_{\mathrm{c}}-\text { cost of the fixed assets that came for } \\
\text { the covered period; } \\
\mathrm{FA}_{\mathrm{e}}-\text { primitive cost of the fixed assets at the } \\
\text { end of the period. }\end{array}$ & $\begin{array}{l}\text { represents part of the fixed assets } \\
\text { put into operation for a year, in their } \\
\text { general present volume, shows a } \\
\text { degree of updating of capital assets } \\
\text { at an enterprise. }\end{array}$ \\
\hline
\end{tabular}


Continue of table 4

\begin{tabular}{|c|c|c|}
\hline Indices & Methodology of calculation & Determination \\
\hline Coefficient of updating & $\begin{array}{l}\qquad \mathrm{C}_{\mathrm{up}}=\frac{\mathrm{FA}_{\mathrm{n}}}{\mathrm{FA}_{\mathrm{e}}} \text {, } \\
\text { where } \mathrm{C}_{\mathrm{up}}-\text { coefficient of updating of the } \\
\text { fixed assets; } \\
\mathrm{FA}_{\mathrm{n}}-\text { cost of the new fixed assets put into the } \\
\text { operation; } \mathrm{FA}_{\mathrm{e}}-\text { cost of the fixed assets at } \\
\text { the end of period. }\end{array}$ & $\begin{array}{l}\text { characterizes part of the new fixed } \\
\text { assets put into an operation for the } \\
\text { covered period in composition of all } \\
\text { fixed assets presented at the end of } \\
\text { the covered period, shows a degree } \\
\text { of updating of capital assets at an } \\
\text { enterprise. }\end{array}$ \\
\hline Coefficient of leaving & $\begin{array}{l}\qquad \mathrm{C}_{\text {leav }}=\frac{\mathrm{FA}_{\mathrm{sh}}}{\mathrm{FA}_{\mathrm{b}}} \text {, } \\
\text { where } \mathrm{C}_{\text {leav }}-\text { coefficient of leaving of the } \\
\text { fixed assets; } \\
\mathrm{FA}_{\mathrm{sh}}-\text { cost of the fixed assets shown out } \\
\text { from exploitation for the covered period; } \\
\mathrm{FA}_{\mathrm{b}}-\text { cost of the fixed assets at the beginning } \\
\text { of the period. }\end{array}$ & $\begin{array}{l}\text { represents specific gravity of the } \\
\text { fixed assets that showed out from } \\
\text { exploitation during a year, in their } \\
\text { general volume, shows a degree of } \\
\text { loss of fixed assets on an enterprise. }\end{array}$ \\
\hline Coefficient of increase & $\begin{array}{c}\mathrm{C}_{\mathrm{inc}}=\frac{\mathrm{FA}_{\mathrm{c}}-\mathrm{FA}_{\mathrm{sh}}}{\mathrm{FA}_{\mathrm{b}}} \\
\text { where } \mathrm{C}_{\mathrm{inc}}-\text { coefficient of increase. }\end{array}$ & $\begin{array}{l}\text { characterizes general tendencies of } \\
\text { motion of the fixed assets at an enter- } \\
\text { prise. }\end{array}$ \\
\hline \multicolumn{3}{|c|}{ indices of technical state of the fixed assets } \\
\hline Coefficient of wear out & $\begin{array}{l}\qquad \mathrm{C}_{\mathrm{wo}}=\frac{\mathrm{W}_{\mathrm{o}}}{\mathrm{FA}} \\
\text { where } \mathrm{C}_{\mathrm{wo}} \text { - coefficient of wear out; } \\
\mathrm{W}_{\mathrm{o}} \text { - sum of wear out of the fixed assets; } \\
\text { FA - primitive cost of the fixed assets. }\end{array}$ & $\begin{array}{l}\text { characterizes the degree of wear out } \\
\text { and compensation of charges on } \\
\text { forming of the fixed assets; is calcu- } \\
\text { lated at the beginning and the end of } \\
\text { the period. }\end{array}$ \\
\hline Coefficient of fitness & $\mathrm{C}_{\mathrm{fit}}=1-\mathrm{C}_{\mathrm{wo}}$ & $\begin{array}{l}\text { shows the degree of fitness of the } \\
\text { fixed assets to exploitation; is calcu- } \\
\text { lated at the beginning and the end } \\
\text { of the period. }\end{array}$ \\
\hline \multicolumn{3}{|c|}{ indices of efficiency of use fixed assets } \\
\hline Fund efficiency & $\begin{array}{l}\qquad \mathrm{F}_{\mathrm{e}}=\frac{\mathrm{C}_{\mathrm{p}}}{\mathrm{FPA}_{\mathrm{av}}} \text {, } \\
\text { where } \mathrm{C}_{\mathrm{p}}-\mathrm{cost} \text { of products made for the } \\
\text { covered period; } \\
\text { FPA }_{\mathrm{av}} \text { - average annual cost of the fixed pro- } \\
\text { ductive assets for period covered. }\end{array}$ & $\begin{array}{l}\text { it is a summarizing index of effi- } \\
\text { ciency of use of the fixed assets; } \\
\text { shows what volume of products is } \\
\text { made on } 1 \text { UAH of the fixed assets. }\end{array}$ \\
\hline Fund capacity & $\begin{array}{r}F_{c}=\frac{1}{F_{e}}, \\
\text { where } F_{c}-\text { fund capacity. }\end{array}$ & $\begin{array}{l}\text { it is reverse index of fund efficiency } \\
\text { that shows level of enterprise provi- } \\
\text { sion with fixed assets }\end{array}$ \\
\hline Fund armed & $\begin{array}{l}\qquad \mathrm{F}_{\mathrm{a}}=\frac{\mathrm{FPA}_{\mathrm{av}}}{\mathrm{C}_{\mathrm{eba}}}, \\
\text { where } \mathrm{F}_{\mathrm{a}}-\text { fund armed, } \\
\mathrm{C}_{\text {eba }}-\text { average accounting amount of em- } \\
\text { ployees of basic type of activity in equivalent } \\
\text { of full employment. }\end{array}$ & $\begin{array}{l}\text { shows size of the fixed assets per } \\
\text { employee }\end{array}$ \\
\hline Income efficiency & $\begin{array}{l}\qquad \mathrm{IE}=\frac{\mathrm{P}}{\mathrm{FA}_{\mathrm{av}}} \\
\text { where IE - income efficiency, } \\
\mathrm{P}-\text { profits from all types of activity, } \\
\mathrm{FA}_{\mathrm{av}} \text { - average annual cost of the fixed assets. }\end{array}$ & $\begin{array}{l}\text { shows volume of profit, that an en- } \\
\text { terprise receives for a unit of present } \\
\text { fixed assets, both those that are in } \\
\text { the use and passed in a lease; }\end{array}$ \\
\hline $\begin{array}{l}\text { Profitability of the fixed } \\
\text { assets }\end{array}$ & $\begin{array}{l}\qquad \mathrm{P}_{\mathrm{fa}}=\frac{\mathrm{NI}}{\mathrm{FPA}_{\mathrm{av}}} \\
\text { where } \mathrm{P}_{\mathrm{fa}}-\text { profitability of the fixed assets; } \\
\mathrm{NI}-\text { net income }\end{array}$ & $\begin{array}{l}\text { shows size of net income that is for } \\
1 \mathrm{UAH} \text { of cost of the fixed assets. }\end{array}$ \\
\hline
\end{tabular}

* generalized by the authors with the use of sources [12,13,14] 
Some scientists in the numerator of formula of profitability of the fixed assets use an index of the financial result before taxation that is the income from all types of activity of the enterprise. In our opinion it is not really correct as the financial result from the regular activity of an enterprise includes the size of taxes paid from income to the budget and, in our view, reduces an effect from the use of the fixed assets.

Realization of the analysis of the fixed assets by given directions will give the possibility to analyse the necessity of expansion or reduction of their amount, define their state and efficiency of use that will allow to improve management of them and to promote efficiency of activity of enterprise on the whole.

Conclusions and prospects of further investigations. Thus, in the article the economic publications devoted to the issues of a concept, classification and efficiency of use of the fixed assets of an enterprise have been studied. The conducted analysis allowed to give determination of the essence of the category "fixed assets", systematize their classification by corresponding features according to the economic and normative sources and conduct the estimation of indices of the analysis of the fixed assets by the directions: the analysis of motion of the fixed assets; the analysis of technical state of the fixed assets; the analysis of efficiency of use of the fixed assets. Realization of the analysis of the fixed assets by given directions will give the possibility to analyse the necessity of expansion or reduction of their amount, define their state and efficiency of use that will allow to improve management of them and promote efficiency of activity of an enterprise on the whole.

\title{
References
}

1. Podatkovyi kodeks Ukrainy: Zakon Ukrainy vid 23.02.2017r., № 1910-VIII. Retrieved May 11, 2017, from http://search.ligazakon.ua/1_doc2.nsf/link1/JF5H901V.html.

2. "Polozhennia (standart) bukhhalterskoho obliku 7 «Osnovni zasoby» : stanom na 18.06.2015r., № 573 ( z0789-15 ). Retrieved May 11, 2017, from http://zakon4.rada.gov.ua/laws/show/z0288-00.

3. Mizhnarodnyi standart bukhhalterskoho obliku 16 «Osnovni zasoby» IASB." Retrieved May 11, 2017, from http://zakon4.rada.gov.ua/laws/show/929 014.

4. Ohiichuk, M. F., Plaksiienko, V. I., \& Belenkova, M. I. Finansovyi ta upravlinskyi oblik za natsionalnymy standartamy. K.: Alerta.

5. Butyntsia, F. F. (2009). Bukhhalterskyi finansovyi oblik (Vol. 8). Zhytomyr: Ruta.

6. Fedorets M.S. (2012). Bukhhalterskyi oblik. Donetsk: DonNUET.

7. Lyshylenko O. V. (2009). Bukhhalterskyi oblik. K.: TsUL

8. Chebanova N.V. (2002). Bukhhalterskyi finansovyi oblik: K.: Vydavnychyi tsentr «Akademiia».

9. Boiko V.M. (1995). Biznes: slovnyk-dovidnyk. K.: Ukraina.

10. Khom'iak R. L., Lemishivskyi V. I. (2007). Bukhhalterskyi oblik v Ukraini. Lviv: Natsionalnyi universytet «Lvivska politekhnika ».

11. Biblioteka ekonomista onlain . Retrieved May 11, 2017, from http://library.if.ua/book/47/3426.html.

12. Shvydanenko H.O., Vasylkov V.H., Honcharova N.P. (2009). Ekonomika pidpryiemstva. K.: KNEU.

13. Poddierohin A.M., Bilyk M.D., Buriak L.D. (2002). Finansy pidpryiemstv. K.: KNEU.

14. Stupnytskaia, T. M. (2010). Otsenka chastnыkh pokazatelei эffektyvnosty yspolzovanyia osnovnoho kapytala . Naukovyi visnyk ODEU. Vseukrainska asotsiatsiia molodykh naukovtsiv: Zb. nauk. prats, 13(114), 3-11.

Received 14 April 2017

Approved 28 April 2017

Available in Internet 30.06.2017

\author{
Ступницкая Т.M. \\ кандидат экономических наук, доцент \\ E-mail: t.stupnitska@gmail.com \\ Гулавская К.И. \\ магистрант \\ кафедра учета и аудита \\ Одесская национальная академия пищевых технологий \\ ул. Канатная, 112, г. Одеса, Украина, 65039 \\ E-mail: katyagulavska@gmail.com
}

\section{ОСНОВНЫЕ СРЕДСТВА ПРЕДПРИЯТИЯ: АСПЕКТЫ ТЕОРЕТИЧЕСКИХ ПОДХОДОВ К ОПРЕДЕЛЕНИЮ ПОНЯТИЯ И ЭФФЕКТИВНОСТИ ИХ ИСПОЛЬЗОВАНИЯ}

Одним из важнейших факторов повышения эффективности производства является обеспеченность его основными средствами. Предприятие содержит основные средства с целью использо- 
вания их в процессе производства, сдачи в аренду другим лицам или для выполнения административных и социально-культурных функций и т.п. В статье рассмотрены экономические публикации по вопросам понятия, классификации и эффективности использования основных средств предприятия. Определена сущность категории «основные средства» в экономической литературе и по нормативным источникам: положению (стандарту) бухгалтерского учета 7 «Основные средства» и Налоговому кодексу Украины, также приведено определение категории «основные средства» по международному стандарту бухгалтерского учета 16 «Основные средства». Систематизирована классификация основных средств по признакам, наиболее распространенным в экономической литературе; рассмотрена классификация основных средств для целей бухгалтерского учета в соответствии с П(С)БУ 7 «Основные средства» на группы, М (С) БУ 16 «Основные средства» на классы и классификация основных средств по Налоговому кодексу Украины. Приведены направления проведения анализа основных средств с использованием соответствующих показателей: анализ движения основных средств; анализ технического состояния основных средств; анализ эффективности использования основных средств. Анализ основных средств по рассмотренным направлениям даст возможность проанализировать необходимость расширения или сокращения количества, определить состояние и эффективность использования основных средств, что позволит улучшить управление ими и повысить эффективность деятельности предприятия в целом.

Ключевые слова: основные средства, классификация основных средств, анализ основных средств предприятия, показатели движения основных средств; показатели технического состояния основных средств; показатели эффективности использования основных средств.

\section{Ступницька Т.М.}

кандидат економічних наук, доцент

E-mail: t.stupnitska@gmail.com

Гулавська K.I.

магістрант

кафедра обліку та аудиту

Одеська національна академія харчових технологій

вул. Канатна, 112, м. Одеса, Україна, 65039

E-mail: katyagulavska@gmail.com

\section{ОСНОВНІ ЗАСОБИ ПІДПРИЕМСТВА: АСПЕКТИ ТЕОРЕТИЧНИХ ПІДХОДІВ ДО ВИЗНАЧЕННЯ ПОНЯТТЯ ТА ЕФЕКТИВНОСТІ ЇХ ВИКОРИСТАННЯ}

Одним із найважливіших чинників підвищення ефективності виробництва є забезпеченість його основними засобами. Підприємство утримує їх з метою використання у процесі виробництва, здавання в оренду іншим особам чи для виконання адміністративних і соціально-культурних функцій тощо.

У статті розглянуто економічні публікації з питань поняття, класифікації та ефективності використання основних засобів підприємства. Визначено сутність категорії «основні засоби» в економічній літературі та за нормативними джерелами: положенням (стандартом) бухгалтерського обліку 7 «Основні засоби» та Податковим кодексом України, також наведено визначення категорії «основні засоби» за міжнародним стандартом бухгалтерського обліку 16 «сновні засоби». Систематизовано класифікацію основних засобів за різними ознаками, що є найбільш розповсюдженою в економічній літературі; розглянуто класифікацію основних засобів для цілей бухгалтерського обліку за вимогами П(С)БО7 «Основні засоби» на групи, М(С)БО 16 «Основні засоби» на класи та класифікацію основних засобів за Податковим кодексом України. Приведені напрями загального аналізу основних засобів з використанням відповідних показників: аналіз руху основних засобів; аналіз технічного стану основних засобів; аналіз ефективності використання основних засобів. Проведення аналізу основних засобів за наведеними напрямами надасть змогу проаналізувати необхідність розширення чи скорочення їх кількості, визначити їх стан та ефективність використання, що дозволить покращити управління ними та підвищити ефективність діяльності підприємства в цілому.

Ключові слова: основні засоби, класифрікація основних засобів, аналіз основних засобів підприємства, показники руху основних засобів; показники технічного стану основних засобів; показники ефективності використання основних засобів. 


\section{Література}

1. Податковий кодекс України: Закон України від 23.02.2017p., № 1910-VIII // [Електронний ресурс]. Режим доступу: http://search.ligazakon.ua/1_doc2.nsf/link1/JF5H901V.html.

2. Положення (стандарт) бухгалтерського обліку 7 «Основні засоби» : станом на 18.06.2015p., № 573 ( z0789-15 ) [Електронний ресурс]. - Режим доступу: http://zakon4.rada.gov.ua/laws/show/z0288-00.

3. Міжнародний стандарт бухгалтерського обліку 16 «Основні засоби» IASB [Електронний ресурс]. - Режим доступу: http://zakon4.rada.gov.ua/laws/show/929_014

4. Фінансовий та управлінський облік за національними стандартами: [підруч.] / [М.Ф. Огійчук, В.Я. Плаксієнко, М.І. Беленкова та ін.]. - [6-те вид., перероб. і допов.]. - К.: Алерта, 2011. - 1042c.

5. Бухгалтерський фінансовий облік: [підруч.] / за заг. ред.Ф.Ф. Бутинця. - [8-е вид., доп. і перероб. ]. Житомир: ПП «Рута», 2009. - 912 с.

6. Федорець М.С. Бухгалтерський облік: [навч. посіб.] / М.С.Федорець, В.С.Терещенко. - Донецьк: ДонНУЕТ, 2012. - 248 с.

7. Бухгалтерський облік: [підруч.] / за ред. О. В. Лишиленко. - К.: ЦУЛ, 2009. - 670 с.

8. Чебанова Н.В. Бухгалтерський фінансовий облік: [посіб.] / Н.В. Чебанова, Ю. А. Василенко. - К.: Видавничий центр «Академія», 2002. - 672 с.

9. Бойко В.М. Бізнес: словник-довідник / В.М. Бойко, П.Г. Вашків. - К.: Україна, 1995. - 565 с.

10. Хом'як Р. Л. Бухгалтерський облік в Україні: [навч. посіб.] / Р. Л.Хом'як, В. І. Лемішівський. - [6-те вид., доп. і перероб.]. - Львів: Національний університет «Львівська політехніка », 2007. - 1200 с.

11. Бібліотека економіста онлайн [Електронний ресурс]. - Режим доступу: http://library.if.ua/book/47/3426.html)

12. Економіка підприємства: [підруч.] / [Г.О. Швиданенко, В.Г. Васильков, Н.П. Гончарова та ін.]. - К.: КНЕУ, 2009. - 598 с.

13. Фінанси підприємств: [підруч.] / [Поддєрьогін А.М., Білик М.Д., Буряк Л.Д. и др.]; за ред. А.М. Поддерьогіна. - [4 -те вид., перероб. та доп.]. - К.: КНЕУ, 2002. - 571 с.

14. Ступницкая Т.М. Оценка частных показателей эффективности использования основного капитала / Т.М.Ступницкая // Науковий вісник ОДЕУ. Всеукраїнська асоціація молодих науковців: Зб. наук. праць. - Одеса, 2010. - Вип. 13 (114). - С. 3-11 